
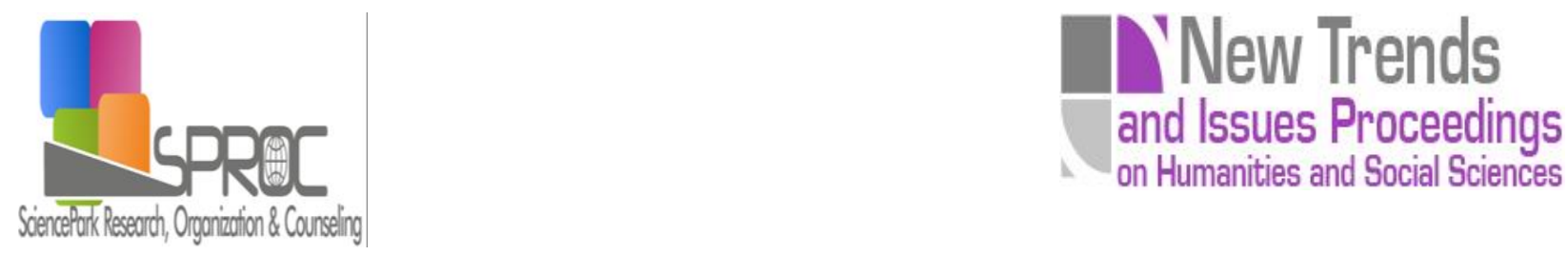

\title{
Performance-Based Budgeting on Strategic Planning: The Case Study in Turkish Higher Education System
}

Mehmet Emin Altundemir

Gonca Gungor Goksu

Suggested Citation:

New Trends and Issues Proceedings on Humanities and Social

Sciences.

Abstract

E-Mail Address:

Gonca Gungor Goksu, 
1. Introduction

2. The conceptual framework of Performance-based Budgeting and Its Use in Higher Education 
New Trends and Issues Proceedings on Humanities and Social Sciences. 
3. Performance-Based Budgeting on Strategic Planning in Turkish Higher Education System 
New Trends and Issues Proceedings on Humanities and Social Sciences. 
New Trends and Issues Proceedings on Humanities and Social Sciences.

4. Conclusion 


\section{References}

Denetimi Sempozyumu Kitabi

Kamu Mali Yonetimi ve

International Higher Education Congress: New Trends and Issues

Funding mechanism and quality assurance systems in highereducation in Egypt in comparative perspective

Kocaeli University, Social Science Journal

International perspectives on performance indicators. Developing performance indicators for higher education South African case study.

Community College Research Center, Columbia University

Sciences 58

Procedia-Social and Behavioral

Swedish higher education.

Prospects for selecting and using indicators for benchmarking

Journal of Higher Education and Science 
Education and Management.

Tertiary

Key performance indicator in Portuguese public universities

TEM Journal

Perspectives of Innovations, Economics and Business 6

Kamu Mali Yonetimi ve Denetimi Sempozyumu Kitabi

Convergence or divergence in international higher education policy: Lessons from Europe.

program preparation guide

Performance

Butce Dunyasi Dergisi.

7. Karaburun Bilim Kongresi.

Educatiom Science Society Journal.

A study on key performance indicators (KPIs) for basic education in Taiwan.

Yuksekogretim

kurumlarinda akademik degerlendirme ve kalite gelistirme rehberi.

Turkiye'nin yuksekogretim stratejisi 